\title{
Examining the Causes of the Establishment of Group Lending Schemes by Women Groups in Zimbabwe
}

\section{Chifamba Raymond Takuraneyi}

Christ College, Zimbabwe

\author{
Shumba Jenny \\ University of Fort Hare, South Africa \\ Email: jennymshumba@gmail.com \\ Maphosa Cosmas
}

University of Fort Hare, South Africa

\section{Doi:10.5901/mjss.2014.v5n16p117}

\section{Abstract}

The study sought to examine causes for the establishment of group lending schemes by women groups in Zimbabwean high density urban areas. A qualitative study located in the interpretive paradigm was employed. A case study design of a purposeful sample of twelve women involved in three group lending schemes participated in the study. Focus group discussion and individual interviews were used to collect data. Content analysis was used to analyse data through emerging themes. The study established a plethora of social, economic and cultural causations to the establishment of group lending schemes. The study concludes that faced with economic challenges, innovative measures are brought to the fore to deal with such challenges.

Keywords: Group lending, high density urban areas

\section{Introduction}

Zimbabwe experienced hyperinflation. Commodities were too high for the ordinary person to afford. Most companies closed down. Sources of income disappeared for many workers. Those who felt it more were the poor, mostly the women and children (Bango, Carlton, Homes \& Reitter, 2010:67). The period in focus that is 2007 to 2011 saw Zimbabwe's economy destabilised as a result of the country's economic and political climate (Bango et al, 2010:68). During this period 2007 to 2011 Zimbabwe went through a difficult time as a country and group lending gave members coping strategies that they could turn into livelihoods.

As most families' income was eroded by the hyperinflation, the economic function of the family had to go on as there had to be food on the table, children had to go to school and rents had to be paid (Huppi \& Fedder, 2010:45).

According to Boserup (2009:76) the period between 2007 and 2011; economic and socio-political environments saw an increasing number of Zimbabweans seeking alternatives livelihood strategies. At community level; women empowerment initiatives in the form of group lending started at tea parties, knitting and sewing clubs. At these gatherings, women discussed the idea of group lending. Group lending was a manifestation of women's drive towards economic freedom.

Most women felt the need to fight poverty that had eroded their homes. Women felt group lending as a means to fight poverty (Chambers, 2009:37). The above statement is supported by March (2008:67) who possess that over the last decade group lending has been promoted as an important tool for poverty education and the achievement tool of the millennium development goods.

Through investigation the researchers observed that most of the women involved in group lending were poor. According to Miles (2010:67) most poor women lack collateral, steady employment and a verifiable credit history and therefore cannot meet even the least minimum qualification therefore the researcher intends to investigate if this is the reasons in Hopley. The above statement is supported by Hulme (2009:63) who notes that group lending is the extension of very small loans to the poor unemployed and others living in poverty who are not considered bankable. 
Barnes (2009:93) posits that women through group lending earn dividends of financial stability, independence and respect . This is what the researcher seeks to find out. The researcher also seeks to find out how these dividends lead to economic empowerment of women.

Through interactions with women in Hopley, it was observed that group lending enables some women to venture into business, for women poultry business, candle making business soap making business, sewing business, cross border business among others. These businesses empower women with extra income for their families. This is in agreement with what (Longwe, 2008:72) possess that group lending provides families with alternative income especially for women and even in times when their husbands do not bring in any income. This is what the researchers sought to find out.

Because of group lending, some women have moved away from destructive coping strategies such as sexual favours or payment for services, smuggling in goods from neighbouring countries where they are cheaper and then get arrested. Savings and lending groups provide a safe, reliable and legal way for members to access financial resources. The groups also establish a social fund, that is, a pool of money that members can access in case of personal emergencies such as funeral or medical expenses (Bango et al, 2010:71; Huppi \& Feder, 2010: 62; Boserup, 2009:105). This is what the research seeks to find out.

According to Moses (2008:72) group lending leads to empowerment of women and participation in the groups opens their minds that they can also be decision makers in the household. As a result the women can be seen as equal partners because they bring in an income. The researcher hopes to find out this in his research.

To answer the question why group lending Bango et al (2010:75) argues that economic emancipation of women is not going to achieved by an individual but by groups .Emancipation here implies empowerment of women.

One of the most noted positive impact of group lending has been a heightened status of women, lessened depending on husbands\{financially\}and improvement of homes national standards for their children they have more control over their spending partners in the household (Longwe 2008:65).

Due to the traditional patriarchal system in Zimbabwe, women suffer from social exclusions. Restriction to the domestic sphere limits social network, participation in civil society and a voice in policy dialogue. Group lending seems to eradicate this group lending overcomes such barriers (Miles, 2010:67). This is what the researcher seeks to find out.

Group lending serves as a medium to communicate health messages. When group members participate in regular repayment meetings, they may be provided with health education, increasing their knowledge of access to formal health care .The regular meetings provided a forum for education and training women capitalize on these meetings to regular contact with a health educator (Moses, 2008:47).

There is also evidence that increased income for women improves child school attendance and internal health attendance and contraceptives use (Huppi \& Feder 2010:78). The above statement is echoed by Miles (2010:72) who possess that social interactions in the group meetings has been found to play an important role on the diffusion of innovative behaviours such as contraceptive use.

However recent evaluations have found that the picture is not always that rosy. Although group lending is found to have rather positive than negative effects in most studies, consensus exists among scholars that group lendings are not panacea for poverty reduction and empowerment (Moses, 2008:63).

According to Moses (2008:64) the negative impact of group lending is about some women in India eroded up committing suicide over failure to repay their debts. Some women end up defaulting from paying the money back, this has a negative effect on the group lending groups (Moses, 2008:72).

Group lending in Zimbabwe is done by women themselves who raise their own capital and also by Nongovernmental organizations, Banks and the government through the ministry of women affairs, gender and community development (Bango et al, 2010:72).

Having given a background on the impact of group lending on women empowerment, it is clear to see that the positive impacts outweigh the negative impacts. Although there are many ways in Zimbabwe to fight poverty and empower women, group lending has not been to its full potential (Bango et al, 2010:83). The researcher seeks to highlight the potential of group lending in eradicating poverty and empowering women.

Whilst some research has been carried out on women empowerment and eradication of poverty, limited efforts have been made to document grave lending and its impacts on women empowerment and eradication of poverty .This is what the researcher hopes to find out by carrying out the research.

Zimbabwe is signatory to the Millennium Development Goals (MDGs) commitments. MDG1: 'eradicate extreme poverty and hunger and MDG3: Promote gender equality and empower women. The ministry of women Affairs, Gender and Community Development is well linked to national efforts to achieve the MOGS hence its support of group lending .Therefore the researcher seeks to find out the impact of group lending through efforts by the government (Bango et al 
2010:102).

Poverty and gender inequality combined have proven and continue to be the greatest socio-economic development challenge in Zimbabwe. In Bangladesh group lending has been cited as a major issue in eradication of poverty and promoting empowerment of women (Bango et al, 2010:89; Moses, 2008: 85; Miles, 2010:76). Therefore, the researcher hopes to find out how group lending in Zimbabwe in general and Hopley in particular leads to empowerment of women. What the researcher does not know yet is whether there has been an inquest or not. This is hoped to be investigated found out revealed by researcher.

The researchers found that there is dearth in literature on group lending. So this has motivated the researcher to carry out investigations in Hopely on the impact of group lending. Because of the paucity on literate on group lending and its impacts on group lending and its impacts on women empowerment; the task at hand is to carry out an investigation on the matter and therefore sensitive to the general population on the importance of group lending and how it impacts on women empowerment.

From the researchers' point of view it is imperative that resources be mobilized to support group lending as vehicle for women empowerment. According to Nachimias (2010:67) group lending promotes equality and equality which leads to the development of the family in particular and the country at large. In addition to group lending reduces poverty and increases women empowerment (Nachimias, 2010:20).

Also people have not seriously considered the effectiveness of group lending to their communities. This could be the reason why there is lack of women empowerment (Bango et al 2010:43). To add to the above statement, this is a problem that mostly men have sidelined group lending as a waste of time (Nachimias, 2010).

\subsection{Statement of the problem}

Nachimias (1996: 67) posits that because of strife of economic decadence, the economic situation led loss of jobs for most breadwinners and in turn it led to poverty in households and led to burden to women. This led to women adopting various coping strategies, for example, business ventures and group lending to avert poverty. Therefore, the researcher wants to find out the impact of group lending on women empowerment. There is paucity in literature on group lending in Zimbabwe. Therefore, the researcher hopes to add to this literature. Hence, the researcher seeks to investigate on the impact of group lending on women empowerment.

\subsection{Research questions}

The researchers sought to answer the following questions.

(i) Why do people engage in group lending?

(ii) What are the challenges faced by people in group lending?

(iii) What is the positive impact of group lending?

(iv) What is the negative impact of group lending?

(v) How can the group lending scheme be improved for the benefit of members?

\subsection{Theoretical Framework}

In this study the researcher uses the Empowerment Theory by Longwe. Longwe (2010:78) posits that disempowerment of women arises from oppression and exploitation of women. For there to be empowerment, Longwe (2010) conceptualises five progressive levels of equality, arranged in hierarchical order with each higher level denoting a higher level of empowerment. These are the basis to assess the extent of women's empowerment in any area of social or economic life. The levels of equality according to Longwe (2010: 80) are:

Control - using the participation of women in the decision making process to achieve balance of control between men and women over the factors of production without one in a position of dominance.

Participation -pertains to women's equal participation in the decision making process, policy making planning and administration. In development projects, it includes involvement in needs assessment, project design, implementation and evaluation.

Conscientisation - pertains to an understanding of the difference between sex roles and gender roles and the belief that gender relations and the gender division of labour should be fair and agreeable to both sides and not based on the domination of one over the other. 
Access - pertains to women's access to factors of production -land, labour, credit, training, marketing facilities and all publicly available services and benefits on an equal basis with men. Equality of access is obtained by securing equality of opportunity through legal reform to remove discriminating provisions.

Welfare - pertains to level of material welfare of women, relative to men with respect to food supply, income and medical care, without reference to whether women are themselves the active creators and producers of their material needs.

In this current research women in Hopley have control over the means of production, that is, land and other business ventures. Therefore, the researcher hopes to find out if women in Hopley are empowered in tandem with Longwe's theory explained above.

The following are models or strategies to empower women through group lending: the first strategy is information / education, both through formal and informal schooling, so that women can obtain knowledge on group lending. When people become aware of the needs of group lending they are moved to fulfill these needs by more participation (James, 2009:72).

The other model is the presence of effective governance to provide a sense of security and justice for all and full protection for women and the poor. A feeling of a sense of protection and security from harm and injustice is basic to local economic development everywhere. It is only when these two strategies above are present that women and as a matter of fact, all citizens, be empowered to fully participate in the economic development of their communities (James, 2010:70). The researcher wonders if the strategies work in Hopley. Therefore, the researchers intended to investigate how the strategies promote women empowerment in Hopley.

\section{Research Methodology}

Research Orientation: This research followed a qualitative research method. Qualitative research is a method of inquiry. It is all about explaining issues, understanding phenomena and answering questions. It is a form of systematic empirical inquiry into meaning. It is designed to reveal a target audience's range of behaviour and the perception that drive it with reference to specific topics or issues (Kothari, 2004:72). Qualitative research is a method of inquiry employed in many different academic disciplines. Qualitative researchers aim to gather an in-depth understanding of human behaviour and the reasons that govern such behaviour. The qualitative method investigates the why and how of decision making, not just what, where, when. Hence, smaller but focused samples are more often needed than large samples. Qualitative methods produce information only on the particular cases studied, and many more general conclusions are only propositions (informed assertions) (Atkinson, 2008:67).

Research Paradigm: The study utilized an interpretive research paradigm. Macdonald (2007:78) argues that the interpretivist paradigm has the idea that truth is negotiated through dialogue. Findings or knowledge claims are created as an investigation proceeds, that is, findings emerge through dialogue in which conflicting interpretations are negotiated among members of a community. In interpretivist paradigm fostering a dialogue between researchers and respondents is critical. It is through this dialectical process that a more informed and sophisticated understanding of the social world can be created. All interpretations are based in a particular moment, that is, they are located in a particular context or situation and time. They are open to re-interpretation and negotiation through conservation.

Research Design: A research design refers to the plan and structure of the investigation used to obtain evidence to answer research questions (Frank, 2005: 37). Booth (1995:63) refers a research design as an outline or strategy chosen by the researcher in an attempt to answer the key issue on the subject being reviewed. The researchers used a case study research design to collect data from respondents. A case study is an in-depth study of a particular situation rather than a sweeping statistical survey. It is a method used to narrow down a very broad field of research into one easily researchable topic (Shuttleworth, 2008: 65). The first step in case study research is to establish a firm research focus to which the researcher can refer over the course of study of a complex phenomenon or object. The researcher establishes the focus of the study by forming questions about the situation or problem to be studied and determining a purpose for the study. The research object in a case study is often a program, an entity, a person, or a group of people. Each object is likely to be intricately connected to political, social, historical and personal issues, providing wide ranging possibilities for questions and adding complexity to the case study. The researcher investigates the object of the case study in depth using a variety of data gathering methods to produce evidence that leads to understanding of the case and answers the research questions (Pigwell, 2007: 76; Brown, 2009:87; Stilth, 2008:95).

Case study research generally answers one or more questions which begin with "how" or "why". For example, research question (i) in Chapter 1 which states, Why do people engage in group lending? The questions are targeted to a limited number of events or conditions and their inter-relationships. To assist in targeting and formulating the questions, 
researchers conduct a literature review. This review establishes what research has been previously conducted and leads to refined, insightful questions about the problem (Lionel, 2008:97; Judith, 2009:87; Jacobs, 2007:101).The researcher chose a case study because it brings out the answers to the questions sought. It leads to understanding of the case.

Population: Nachimias (1996: 47) defines a population in a research as the aggregate of all the cases that conform to some designate set of specifications. In Hopley the people involved in group landing were about 430. This serves as the population. So the sample the researcher will look at is approximately 60 people and three community leaders.

Sample and Sampling Procedure: Purposive sampling was used and 60 women practicing group lending and three community leaders were purposively sampled. Purposive sampling can also be called judgmental sampling. It is a non-probability sampling. With this research the researcher chooses the sample based on who they think would be appropriate for the study. This is used primarily when there is limited number of people that have expertise in the area being researched (Mark, 2009:47). Group lending and its impact to women empowerment is such an area that has not been well researched.

Data Collection Methods: In this research focus group discussion and individual interviews were used as primary data collection. There are documents by other researchers like the internet, newspaper, journal magazine, report and articles. Among the documents used by the researcher are sociology textbooks.

Research Instruments: The research instruments which were used are interviews and focus group discussion. The researcher used in depth interview. This is an interview with a single individual typically lasting 30 to 90 minutes, depending on the subject matter and context. It may be conducted in person at a research facility, the respondents' home or workplace or a public location or by telephone (Charles, 2008: 83). Boyce and Neale (2006) argue that interviews allow the researcher to get in-depth deformation on the study and people can express themselves on a one on one talk. Interviews were targeted at 60 different women involved in group lending around Hopley. Prior to each interview, the interviewer established a friendly relationship with subjects and there was assurance that no personal details were required. Hence, maintenance of privacy, confidentiality and enormity throughout the study was stressed. Interviews are to be conducted in English for those who had interest on using the language, for those with problems or difficulties in English, Shona will be used.

The study also employed focus group discussion. Focus group discussion is a moderator led discussion among a group of individuals who share a need, habit of life circumstance relevant to the research issues at hand. Typically one or two hours in length, a focus group discussion often includes from two to ten respondents. Group discussion can be held in person, that is, face to face (Livite, 2007:79). Focus group will be used on 12 people.

Focus group discussion is a method of gathering data from a group of people. It allows interviewers to study people in a more natural setting than a one to one interview. It can be used to various cultural and social groups, selecting sites to study, sampling of such sites and raising unexpected issues for exploration. The main advantage is that they are fairly low on cost. Also one can get results relatively quickly. The researcher can talk to several people at once (Knoxy, 2008:83). These will be members of the same group.

The researchers also analyse documents such as constitution, record book and minute book to check on the impact of group lending on women empowerment.

Data Analysis: Bute (2009:78) defines data analysis as the process of evaluating data using analytical and logical reasoning to examine each component of the data provided with a goal of highlighting useful information, suggesting conclusions and supporting decision making. Therefore the researcher will gather, review and then analyse data from various sources to form some sort of finding or conclusion, for example sources like statements, focus group discussions, face to face interviews.

Measures to Ensure Trustworthiness: Measures of trustworthiness in this research will justify the results of the research. The researcher would seek purity and consistency so that if someone else repeated the same study they will come up with the same result. According to Johnson (1997:62) in qualitative research three types of validity can be discussed that makes a research trustworthy. First, descriptive validity refers to the factual accuracy of the account as reported by the qualitative researcher. Second, integrative validity is obtained to the degree that the participant's viewpoints, thoughts, intentions and experienced are accurately understood and reported by the qualitative researcher. Third, theoretical validity is obtained to the degree that a theory or theoretical explanation developed from a research study fits the data and is therefore credible and defensible.

When possible, qualitative researchers should collect data in the field over an extended period of time (Michael, 2007:72). This enables the researcher to have accurate data. The researcher will use low inference descriptors that is, the use of description phrased very close to the participants accounts and researchers field notes (Smith, 2008:93). The researchers used verbatim accounts (that is direct quotation). 
The researchers used triangulation, that is, "cross checking" information and conclusions through the use of multiple procedures of sources. When the different procedures or sources are in agreement you have "corroboration". The researchers used data triangulation, that is, the use of multiple data sources to help understand a phenomenon on the impact of group lending on the empowerment of women.

The researchers made use of investigator triangulation, that is, the use of multiple investigators, that is, multiple resources in collecting and interpreting the data. The researchers used participant feedback, that is, the feedback and discussion of the researcher's interpretations and conclusions with the actual participants and other members of the participant community for verification and insight.

Lastly, the researchers used peer review, that is, discussion of the researchers' interpretation and conclusions with other people. This includes discussions with a disinterested peer for example, with another researcher not directly involved. This peer should be skeptical and play the "devil's advocate", challenging the researcher to provide solid evidence for any interpretations or conclusions.

Ethical Considerations: The researchers ensured right to privacy. Names of participants were not revealed. The researchers kept from public certain information about participants, for example, the women's ages and marital status. In addition researchers avoided unnecessary questions which expose the respondent. The researchers obtained direct consent for participation in the research. Furthermore researchers ensured that there was participants' right to confidentiality.

\section{Results and Discussion}

\subsection{Biographic Data.}

Table 1: Showing biographical data of respondents

\begin{tabular}{|c|c|c|c|}
\hline Age & Number of Interviewees & Married Women & Single mothers \\
\hline $25-29$ years & 4 & 4 & 0 \\
\hline $30-39$ years & 4 & 2 & 2 \\
\hline $40-49$ years & 4 & 2 & 2 \\
\hline
\end{tabular}

The above shows the distribution of the participants in accordance with age and their marital status.

\subsection{Marital Status}

A total of 12 women were interviewed by the researcher, four of them were between the age of 25-29. All these were married. Two out of four women within the age range of 30-39 were married. Two were single from the age of between 40-49, whilst two were married. The researcher thinks that marital status had some significance to the findings because, probably married women might want to supplement the incomes of their husbands and so end up engaging in group lending. Single mothers might be forced to engage in group lending probably because they have no option, they have no spouses to take care of them and their families. The age range of the women interviewed were involved in group lending probably because they had families or children and so it was their obligation to look after their families. They could not just sit and look after their families. They could not just sit and cook whilst their children suffered. They had to run around to look for some money to look after their families. It should be noted that unlike the age range of 24 years and below, most of them will be girls under guidance from their parents. Therefore they are supported by their parents, but as one gives birth and/or becomes married, she runs around looking for money to sustain her family. So this is probably why such women are engaged in group lending.

\subsection{Level of Education}

From the twelve women interviewed, seven of them were educated up to "O" level. However they did not attain five "O" level subjects; five of them had dropped out of school and did not write the "O" level examination. From the researcher's point of view, the above cares show that such women engaged in group lending probably because of failure to attain five "O" level subjects, the women failed to access formed employment which requires people with five "O" levels. So the women were probably forced to engage in group lending as a survival strategy. They wanted to cope with life through group lending. 


\subsection{Reasons for joining group lending scheme.}

All the twelve women interviewed agreed that they got engaged in group lending because they wanted to uplift their livelihoods as the economy of the country got worse from the year 2001.

One woman was quoted saying:

As from 2001, money was difficult to come by. The only way to survive for me was through joining a group lending scheme.

The above quotation is supported by Bango, Carlton, Homes and Reitter (2010:67) who post that Zimbabwe experienced hyperinflation; those who felt it more were the poor, mostly the women and children. As a result group lending gave women coping strategies that they could turn into livelihoods.

\subsection{Economic Exclusion}

Another woman was quoted as saying:

Group lending removes women from deprivation and exclusion for example poverty. Poverty level in Zimbabwe and Hopley in particular were high from the 2007 to 2008. Rates of economic growth were very low. The overall rise in poverty made the con-current increase in income and asset inequality with women in Hopley at a particular disadvantage.

One woman said:

The consumption expenditure for Hopley families rose significantly. Women suffered greatly. Indicators to show people in Hopley were poor are, low consumption, no formal education, high rates of infant mortality and lack of access to essential services. This segment of the poor population in Hopley was particularly vulnerable to factors that increased deprivation like health emergencies, unstable livelihoods and poor sanitation.

One woman concurred with the above statement, she said:

Such chronic insecurity mentioned led to livelihood strategies that prevent mobility out of poverty such as irregular day labour at the "round about", begging and sex work. As a result when most of the women heard of group lending they considered the costs of group lending and saw that the advantages were plenty and so decided to join group lending schemes.

The above statements on economic exclusion are supported by Boserup (2009:29) who highlights that group lending was a manifestation of women's drive towards chronic freedom.

\subsection{Spatial Exclusion}

One woman said:

Because of the low geographic locations uneven distribution of services and infrastructure, low agricultural or resource potential women in Hopley were excluded. Therefore the women engaged in group lending felt that the only way to get themselves out of poverty was to form group lending schemes.

The above statement is supported by Amin (2005:117) who posits that geographic location can exclude people from economic growth.

\subsection{Cultural exclusion}

A woman interviewed said cultural exclusion can limit people from economic growth. She is quoted as saying:

Culturally some women are still confined to work in the domestic sphere where it is under-valued and not remunerated.

Restriction to the domestic sphere limits social networks, participation in civil society and voice in policy dialogue.

Therefore this forced them to break such barriers and join group lending. 
Moses (2008:25) supports the above statement by saying that, "Although women are culturally restituted, they force their way to gain economic freedom."

\title{
3.8 Social Capital and Social Exclusion
}

The women agreed that they were forced to join group lending and wanted to form social capital. This is what one woman said;

I had that group lending can develop new social Capital and networks for participants. The mutual support and solidarity of the group provides an atmosphere of collective self-interest. When one joins a lending group there is social inclusion. One becomes a member to the lending group. However social inclusion is hindered by people who defer on their payments and so are punished with reclamation of their assets and social sanction, this results in social exclusion.

To support the above statement Collins (2001:96) who answers that most women join group lending to gain social capital and social inclusion.

There are also different economic reasons why people join group lending. This can be summed up by the following women's statements:

I got involved in group lending because money was tight to come by. In my efforts to run around looking for money, a woman introduced me to a group that was engaged in group lending. After I joined the group, I have been able to make ends meet than previously. Group lending has helped me to improve my livelihood. I joined group lending because my husband had died. He was the sole breadwinner. Life became so difficult for me and my family. One woman introduced me to some group lending members, they asked me to join. I decided to try and see, from there onwards I have never looked back.

It seems from the above that women who join group lending due to various reasons, some of them being economic reasons. When people cannot make ends meet they look for other means to try and cope with economic situations, Chamber (2001:87).

This woman had a rather different reason:

\begin{abstract}
I heard that there were some women who were engaged in group lending. At first I thought that this was useless, I never thought of joining. The women kept on encouraging me to join and so I joined just to please them. However afterwards I realized that group lending was the way to go. It later changed my life. I am now involved in the business of making peanut butter. Now I can at least buy food for my family and send them to school.
\end{abstract}

From the above it seems some women join group lending due to peer pressure, Kate (1995:76).

The above is also concurred by this woman who had this to say:

Through discussion with other women I was made to realize the impact of group lending. I did not hesitate to join. After some time after joining, I realized that group lending gave me a start to uplift my life and that of my family. If it was not because of my colleagues I do not know where I would be.

Apart from peer pressure as a reason for joining lending groups, other reasons arrange such as group lending gives members a new lease of life, James (2010:86)

Married women said wages from their husbands become little and little every month as from 2007. As a result the money was chasing to money goods and services. As a result they wanted to supplement their husband's wages. So they joined lending groups. Here is a quotation from one woman:

The period from 2007 to 2008 was difficult especially for my husband. The money he earned could not last us the whole month. We discussed the issue with my husband on what one should do. I convinced him that I should join a group lending scheme. After I joined I started "burning" money or exchanging money in town. The profit I got, I joined a lending group.

From the above it shows that group lending is done by the poor who fail to make ends meet. Although the rich people also engage in it, it is mostly the poor people who do (John, 1992:59).

Some women join lending groups after observing what other women benefited. One woman had this to say: "After seeing what those women engaged in the group lending benefited I decided to join." 
Midglery (1986:37) supports the above statements by saying that some people have a "wait and see" attitude. They wait to see the outcome of something so as to act or react afterwards.

Some women said they joined group lending to strengthen their relationship.

We engaged in group lending apart from economic reasons to engage in various discussions that mold our behavior as women at home and in the public. Group lending strengthens our relationship. We inform, entertain and educate each other on different topics.

Group lending has been proven to strengthen relationships among group members, Hulme (2009:77).

Three community leaders asked on why people join lending groups, they said,

\begin{abstract}
Women in the community engage in group lending schemes for different reasons. Some join such schemes to fund for several types. Of needs, for example, life cycle needs the likes of weddings, funerals, childbirth, education, home building, widowhood, old age; Personal emergencies like sickness, injury, un-employment, theft, death; disasters like fires and investment opportunities like expanding a business, buying land or equipment, improving housing or securing a job.
\end{abstract}

Holland (2001:94) points that people engage in group lending schemes to fund various types of needs.

The three community leaders also had this to say on why people engage in lending groups.

Women join group lending schemes because traditionally banks have not provided financial services such as loans to clients with little or no cash income. Most poor people especially women in this area have few assets that can be secured by a bank as collateral. Banks need endowment (material or non-material collateral) which the women do not have.

People engage in group lending as a way of running away from banks that require collateral. Group lending is the easiest way of getting money as it does not need collateral, Rollinson (2008:63).

Women interviewed through group discussion said women join lending groups for different opportunities this is one of them said, "People join group lending schemes because they provide new opportunities for people on economies like ours."

People in transitioning economies join lending group schemes for new opportunities like advice, connections and potential markets (Cagon, 2009:78).

One woman said she joined group lending because those who were available to give money charged high interests. For example she said, "I joined group lending schemes to run away from money lenders whose interests are too high."

Brooks (2008:91) states that people join group lending schemes because they want to run away from money sharks who want to take advantage of the desperate situation in people.

In response to the question, "How did you hear about group lending activities?"

One woman interviewed had this to say:

I heard about group lending activities from my church members when I told them about how I was struggling to make ends meet. They told me that most women are engaging in group lending schemes to ease financial problems.

The other woman said:

Through discussion with my friends I learnt that my friends were engaged in group lending schemes, so they invited me to join. Ever since I joined I have never looked back.

Another woman said:

We heard about group lending from an organization called Zimbabwe Women's Bureau. The organization invited women for training on group lending, so we attended the workshop; from there we formed a lending group. Several groups were also formed.

From the above statements it looks like peer pressure contribute to people to form lending groups, also other groups or organisations can contribute to people forming lending groups, Moses (2008:83). 


\subsection{Regrets for joining a lending group}

Most women asked this question said they had no regrets.

I do not regret joining a lending group. Group lending has given me a kick start in life. It has improved my standard of living.

I have no regrets so far it has uplifted me in my livelihood. We properly selected our group members. They are participating well in the group. Everything is going on well.

According to Miles (2010:28) group lending if properly carried out has no problems.

However there are problems that make group members to regret ever joining lending groups.

Some problems arise in leading groups that make them a bit worried, such as problems are that some members default in paying back the loan. This jeopardizes the whole efforts of the group. At times we regret ever joining the group lending scheme.

Views from the respondents indicated that there were numerous reasons that motivated women to participate in group lending schemes as an innovative way of dealing with financial challenges caused by the hyper inflationary environment.

\section{Conclusions}

From the findings, the researchers conclude that group lending is practised by women to meet their needs since some of all those living in extreme poverty are female. The greatest opportunity for interrupting cycles of extreme poverty come from group lending programmes that target females. When women improve their circumstances, they also improve the lives of their children. By increasing in nutrition and education, they help to create a better future for their children and their communities.

\section{Recommendations}

Group lending should be promoted in order to help poor people especially women out of poverty. It is also a way of promoting economic development, employment and growth. The poor stay poor, not because they are lazy, but because they have no access to capital. Till today a large number of poor people remain outside the formal banking system. The role of group lending is to reach this set of the population that remains unbankable or unbanked and make financial services accessible to them.

There is a saying, "Give a man a fish and you feed him for a dog. Teach a man to fish and you feed him for a lifetime." When it comes to lifting people out of poverty there is little doubt that you can accomplish a lot more by empowering people than offering hand out after hand out, and that is the primary reason for supporting group lending.

Funds should be made available to women by banks and the government. Instead of lending directly to individual borrowers money should lend to groups of borrowers who are jointly liable for a single loan. This would serve several mutually reinforcing purposes. Group lending minimizes administrative and transaction costs for lenders by replacing credit checks and collateral processing with self-selection of groups by borrowers. Borrowers who are jointly liable for the loans of their group have a vested interest in choosing trustworthy partners. Joint liability also discourages default because group members exercises peer pressure to repay on their partners, as well as providing a business support network that offer advice, correction and potential markets. The model works by generating revenue through interest in which is paid by each borrower to help finance the cost of lending the others. Such a model can lead to self-sustaining micro lending programs that cover their own costs. A successful program will generate more resources with each individual helped because of added interest, which enables program to generate more income than they actually spend helping more people in need. These mechanisms towards self-sustaining and even profit making ventures have lead some banks to both profitability and serve the workers poor. Indeed group lending is fast emerging as a powerful instrument for poverty alleviation in growing economies.

Subsidies from donors and government should be there for the poor women. Government should encourage integrating the financial needs of the poor women into the country's system; the job of government is to enable financial services. The key bottleneck to formal group lending schemes is the shortage of strong institutions and managers. Interest rate ceilings hurt the poor; government should encourage micro finance institutions not to increase group-lending 
costs, which choke off the supply of credit. Help can come in the form of more and better-qualified staff, thus higher education is needed for micro finance institution staff.

\section{References}

Amin, Z. (2005). Women in Business, empowerment London: Bogle Publications

Atkinson, L. 2008. Third World Nations in Business, Cape Town: Hammondsworth

Bango, S., Carlton, I., Homer, T. and Reitter, E. (2010). Poverty in Africa, Harare: Sapes

Booth, T. 1995. Business Ethics, Australia: Business Press.

Boserup, B. (2009) Dynamics of Sociology, London :Penguin Books.

Boyce, C. and Neale, P. (2006). Conducting In-depth Interviews: A Guide for Designing In- depth Interviews for Evaluation Input. http://www.pathfind.org/site/DocServe/m e tool series indepth interviews.pdf?doclD=6301. Accessed 4 March 2014.

Brown, S. (2009). Business Entrepreneurship, London: McGraw Hill.

Bute, J. (2009).Women and Business, New Delhi: New International Age Limited Publishers.

Cagon, N. (2009). Third World Business, Hong Kong: Polity Press

Chambers, T. (2009). Business in Developing Countries, New York: March Decker.

Charles,P. (2008). Gender Dynamics, Tokyo: The Free Press.

Collins, L. (2001). Gender and Equality, New York: St Martins Press.

Frank, F. (2005). Ethics in Economic Growth, New Delhi: Philadelphia Irwin Books.

Hylland, T. (2001). Development, London: Pluto Press

Hulme, M. (2009). Gender Equality and Equity, London: Routledge.

Huppi, T. \& Fedder, E. (2010). Essentials of Development in Third World Countries, Tokyo : Amazon Press.

Jacobs, B. (2007). Microfinance Dynamics, London: Pluto Press.

James, S. (2009). Microfinance Dynamics, London: Pluto Press.

John, J. (1992). Women and Development, New York: Routledge.

Johnson, H. (1992). Microcredit in Developing Countries, Cape Town: St Martins Press.

Judith, T. (2009). Management of Group Lending, Hong Kong: Longman.

Kate, T. (1995). South to South Micro-Credit, Hong Kong: Earth Scan Publishers.

Knoxy, K. (2008). Research: A Practical Guide, Pretoria: Ethethuko Investment Publishing.

Kothari, R. (2004). Research Methods, Sydney: Freedom Press.

Lionel, C. (2008). Research Projects, Cape Town: Juta and Company Ltd.

Livite, C. (2007). Social Science Research, New York :March Dekker.

Longwe, N. (2008). Women Empowerment Framework: Harare Longman.

Macdonald, B. (2007). The Art of Research Projects: Chicago College Press.

March, H. (2008). Economic Analysis of Microfinance, Illinois: The Free Press.

Mark, R. (2009). Research Methods: A Guide to Students, London: McGraw Hill.

Michael, I. (2007). Research Methods: A Guide to Students, London: McGraw Hill.

Midgley, T. (1986). Developing Nations, Cape Town: Penguin Books.

Miles, M. (2010). Sociology in Development, London: Polity Press.

Moses, R. (2008). Sociology Perspectives, London: Hammondsworth.

Nachimias, T. (2010). A Guide to Microcredit, New York: St Martin Press,

Pigwell, W. (2007). A Practical Guide to Research, New York: Prentice Hall.

Rollinson, N. (2008). Sustainable Economic Development, London: Prentice Hall.

Shuttleworth, D. (2008). Economic Development, New York: Prentice Hall.

Smith, H. (2008). Research Dissertation, London: Polity Press.

Stilth, H. (2008). Advanced Research Methods, London: Lambert Academic Publishing. 